\title{
1 The coronavirus SARS-CoV-2 and its impact on the world
}

\author{
Andrzej Nowosad, Ümit Turanli, and \\ Katarzyna Lorenc
}

\subsection{Introduction}

Severe acute respiratory syndrome coronavirus (SARS-CoV-2) ${ }^{1}$ (Gorbalenya et al. 2020: 536) is the virus that causes the coronavirus disease 2019 (COVID-19), the respiratory illness responsible for the COVID-19 pandemic (BBC: February 11, 2020). ${ }^{2}$ The World Health Organization (WHO) declared the disease a Public Health Emergency of International Concern on January 30, 2020 and a pandemic on March 11, 2020 (WHO: January 30, 2020; WHO: March 11, 2020). The last time WHO announced a pandemic was during the $2009 \mathrm{H} 1 \mathrm{~N} 1$ outbreak $^{3}$ (the 2009 swine flu pandemic), which infected nearly a quarter of the world's population. ${ }^{4}$

The so-called Wuhan virus (COVID-19) spreads among people primarily through close contact and via respiratory droplets produced by coughs or sneezes, and epidemiological studies estimate each infection results in 5.7 new ones (Sanche et al. 2020). Each case of infection has an individual

1 SARS-CoV-2 is a positive-sense single-stranded RNA virus (Machhi et al. 2020: 359-386) and hence Baltimore class IV (Baltimore 1971) that is contagious in humans (Chan et al. 2020). As described by the US National Institutes of Health, it is the successor to SARSCoV-1, the virus that caused the 2002-2004 SARS outbreak (NIH: March 17, 2020).

2 Colloquially known simply as 'the coronavirus', it was previously referred to by its provisional name, 2019 novel coronavirus (2019-nCoV) (WHO January 2020 Report; CDC February 11, 2020) and has also been called human coronavirus 2019 (HCoV-19 or hCoV-19) (Andersen et al. 2020: 450-452).

3 In virology, influenza A virus subtype $\mathrm{H} 1 \mathrm{~N} 1(\mathrm{~A} / \mathrm{H} 1 \mathrm{~N} 1)$ is a subtype of Influenza A virus. Well-known outbreaks of H1N1 strains in humans include the 2009 swine flu pandemic as well as the 1918 flu pandemic. It is an orthomyxovirus that contains the glycoproteins haemagglutinin and neuraminidase. For this reason, they are described as H1N1, H1N2 etc. depending on the type of $\mathrm{H}$ or $\mathrm{N}$ antigens they express with metabolic synergy (Lim, Mahmood 2011).

4 The 2009 swine flu pandemic was an influenza pandemic that lasted about 19 months, from January 2009 to August 2010. The number of lab-confirmed deaths reported to the World Health Organization (WHO) is 18,449 , though the $2009 \mathrm{H} 1 \mathrm{~N} 1 \mathrm{flu}$ pandemic is estimated to have actually caused about 284,000 (range from 150,000 to 575,000 ) deaths. 
course of the disease. Usually, the virus causes a severe inflammation of the airways but it also affects other organs and organ systems.

As of September 8, 2021, there have been 222,903,649 total confirmed cases of SARS-CoV-2 infection during the ongoing pandemic and the number of virus infections is increasing quickly, particularly in the United Kingdom and in the United States. The total number of deaths attributed to the virus is 4,603,035 (CSSE: September 8, 2021). And although it should be noted that many recoveries from both confirmed and untested infections go unreported since some countries do not collect this data, at least 199,461,542 people have recovered from confirmed infections (CSSE: September 08, 2021). The number of confirmed cases is lower than the number of actual cases; the main reason for that is limited testing.

The large scale of the COVID-19 pandemic is causing unprecedented human and economic costs throughout the world. Trying to reduce the spread of the virus and thus the number of people infected and deceased, most state governments in the world introduced limitations for many industries and activities, which contributed to the ongoing economic decline. In this chapter, we analyze the origins, development, and current state of the COVID-19 epidemic, the ways in which the governments are trying to fight the deadly virus and the economic crisis caused by the pandemic, and the differences in perception of the threat caused by COVID-19. We also mention new challenges the world faces in 2021 as well as introduce the reader to the broad spectrum of costs of the pandemic, including the possible costs for people's mental health.

\subsection{Origin and spread of SARS-CoV-2}

The origin of SARS-CoV-2 coronavirus has not yet been explained. Journal of Medical Virology (three special issues on the Novel Coronavirus (COVID19), 2019, 2020) indicated snakes (serpentes), then bats (chiroptera), and currently Asiatic pangolins, sometimes known as scaly anteaters (manidae), ${ }^{5}$ as the source of the coronavirus disease. There are also a lot of theories on how the virus transferred to humans. However, none of them is coherent and reliable enough and publications on this subject are increasingly moving away from the norms of scientific literature.

Coronavirus SARS-CoV-2 (originally called 2019-nCoV) was officially identified for the first time in the Chinese city of Wuhan (武漢市) in the province Hubei (湖北) in central China in December 2019. However, it can be assumed that it had already affected humans earlier as Spanish virologists found traces of the novel coronavirus in a sample of Barcelona wastewater collected in March 2019, nine months before the COVID-19 disease was

5 Shou-Jiang (ed.) 'Three special issues on the Novel Coronavirus (COVID-19)', Journal of Medical Virology, monthly editions for years 2019-2020. 
identified in China (Reuters: June 26, 2020). But there is no reliable data on the source of the SARS-CoV-2 and the geography of its spread before it was identified in Wuhan, and this very fact caused speculations that China spread the virus around the world.

Currently, there are many hypotheses about how this dangerous virus was released - from global warming and melting glaciers to being artificially created in a military laboratory as a new kind of biological weapon. Disagreements on this topic among scientists and members of the public are accompanied by conspiracy theories pouring globally into the media, thanks to which they gain the popularity and trustworthiness of scientific theories.

The claims of virologists and "experts" are also not consistent. Some claim that they have sufficient evidence that SARS-CoV-2 coronavirus was produced naturally, in wildlife not in a laboratory, and that SARS-CoV-2 coronavirus is not suitable for biological weapons. Others say the opposite and claim that the virus has "escaped" from a Chinese laboratory (see the statement by the US President Donald Trump from May 1, 2020 (The Guardian: May 1, 2020)).6

\subsection{SARS, MERS and COVID-19}

The human coronavirus was first identified in 1962 in a child with cold symptoms and was called B814. Since then, six species of this type of virus have appeared in the world. The most severe diseases were caused by SARS in 2003, with 812 deaths, and MERS-CoV which between 2012 and 2017 resulted in the deaths of 712 people. SARS-CoV-2 is the seventh known coronavirus that is dangerous for humans. COVID-19 does not cause high mortality compared to acute respiratory failure MERS-CoV or SARS. However, it spreads rapidly and has already caused more deaths worldwide than SARS and MERS combined.

According to Worldometer Data (WMD) (https://www.worldometers .info/coronavirus/, data collected as of December 31, 2020), there were $83,135,180$ global cases of COVID-19 infection by the end of 2020, of which 1,813,389 cases resulted in humans' death, and 58,933,056 people recovered. The coronavirus COVID-19 is affecting 218 countries and

6 "Donald Trump claims to have seen evidence to substantiate the unproven theory that the coronavirus originated at the Wuhan Institute of Virology, despite US intelligence agencies' conclusion that the virus was 'not manmade or genetically modified'. 'We're going to see where it comes from,' Trump said at a White House event on Thursday. 'We have people looking at it very, very strongly. Scientific people, intelligence people, and others. We're going to put it all together. I think we will have a very good answer eventually. And China might even tell us.' Pressed to explain what evidence he had seen that the virus originated in a Chinese lab, Trump responded, 'I can't tell you that. I'm not allowed to tell you that'” (The Guardian: May 1, 2020). 
territories around the world and two international conveyances. The fatality rate is still being assessed (WMD: December 31, 2020).

When it comes to the pandemic's development over time, as of September 08, 2021, we are expecting the fourth wave, we are experiencing the third wave of an increased number of people infected. After originally erupting in China in November and December 2019, the first worldwide wave of the COVID-19 pandemic started at the end of March 2020 and peaked in April 2020. Governmental responses across countries differed greatly at that time, from severe lockdown introduced in Italy - the country most affected among those in Europe - to the United Kingdom and Sweden who were convinced that the economic and social costs of a lockdown would be too big and decided against introducing severe restrictions, at least at the beginning. The summer of 2020 brought hope, encouraging many governments to lower restrictions and people to protest against the restrictions as the numbers of new COVID-19 cases dropped in many countries. However, in October and November 2020 it became clear that the second wave of the pandemic was inevitable. This time, similar but often less severe restrictions were introduced around the world. Spirits were kept up by the news about vaccines against the deadly virus which were already invented and during the last phases of testing. After reaching peaks in the winter of 2020, the beginnings of 2021 saw a decline in the worldwide number of new COVID19 cases. From late December 2020, the vaccination process started as well, letting some experts believe that the COVID-19 pandemic was a thing of 2020. However, as new virus mutations appeared in the United Kingdom and South Africa and the European Union governments avoided early implementation of a new lockdown, in March 2021 the third wave of the pandemic began, leaving experts to wonder about the future (Johns Hopkins University: March 25, 2021).

Geographically, the highest number of cases of infection and death have been reported in the United States (41,206,672 total cases and 669,022 total deaths), India (33,096,718 total cases and 441,443 total deaths), Brazil (20,913,578 total cases and 584,208 total deaths), Russia (7,065,904 total cases and 189,582 total deaths), the United Kingdom (7,056,106 total cases and 133,483 deaths), France (6,854,028 total cases and 115,159 total deaths), Turkey (6,542,654 total cases and 58,651 total deaths), Argentina (5,211,801 total cases and 112,851 total deaths), Iran (5,210,978 total cases and 112,430 total deaths), Colombia (4,921,410 total cases and 125,378 total deaths), Spain $(4,892,640$ total cases and 85,066 total deaths), Italy (4,579,502 total cases and 129,638 total deaths), Indonesia (4,147,365 total cases and 137,782 total deaths) and Germany (4,029,849 total cases and 92,949 total deaths), Mexico (3,449,295 total cases and 264,541 total deaths), Poland (2,891,602 total cases and 75,403 total deaths), (September 08, 2021).

Moreover, it should be noted that many cases and deaths have not been statistically recorded as they have been asymptomatic, and not every country has provided reliable data on cases and deaths. 


\subsection{Virus denial and miscalculations}

One of the biggest problems connected with the pandemic is that many countries around the world have denied the existence of the pandemic and the virus itself, or have neglected the threat. The well-known examples of such a denial include Russia, Belarus, Turkmenistan, and Azerbaijan, which even decided to organize mass sporting events during the pandemic. What is more, the US President Donald Trump, the British Prime Minister Boris Johnson, the Russian President Vladimir Putin, the Polish President Andrzej Duda, the Brazilian President Jair Bolsonaro, and the Mexican President Andres Manuel Lopez Obrador have repeatedly downplayed the coronavirus threat. This "cavalier" leadership approach as well as the lack of social safety nets and strong public health systems have worsened the crisis. The lack of an effective response to the virus's spread in the United States, the United Kingdom, Brazil, Poland or Russia has been one of the most surprising developments of the pandemic.

With some political leaders openly neglecting the threats of the COVID19 pandemic, so do the people as well. Those affected strongly by governmental restrictions - denied the right to run their businesses, losing jobs, or just opposing the fact that a lot of human, political, and social rights have been suspended for a year now and probably also for the indefinite future - express their skepticism towards the measures taken by the governments and even raise concerns about the existence and extent of the pandemic itself. According to the YouGov-Cambridge Globalism Project that included a survey of about 26,000 people in 25 countries, significant groups of people believe that the death rate of the virus is deliberately exaggerated to a large extent. This statement is believed by $59 \%$ of Nigerians; $46 \%$ of Greeks; over $40 \%$ of Poles, South Africans, and Mexicans; about $38 \%$ of Americans; $36 \%$ of Hungarians; $30 \%$ of Italians; $28 \%$ of Germans; and $22 \%$ of Britons. In 10 out of 25 countries studied, $20-30 \%$ of respondents go even further, claiming that the pandemic is a hoax to deceive people (The Guardian: October 26, 2020).

Even if not doubting COVID-19 itself, many people around the world are tempted to believe in one or more of several leading conspiracy theories connected with the virus. More than $50 \%$ of Nigerians; more than $40 \%$ of South Africans, Poles, and Turks; more than 30\% of Americans and Brazilians; and more than $20 \%$ of French, Britons, Italians, and Germans believe that the virus has been deliberately created and spread by China (The Guardian: October 26, 2020). There are also many others who think that COVID-19 is not more harmful than regular flu, that there is no need to wear a mask and that the vaccines are unsafe or include miniature devices that may be used to spy on people (Scientific American: October 12, 2020).

Those skeptical of the COVID-19 threat and the necessity of measures taken to fight it do not only express their concerns through social surveys but also engage in many communication activities, from Facebook groups 
dedicated to different COVID-19-related conspiracy theories to public gatherings organized to protest against the restrictions. For example, on August 29, 2020, over 10,000 unmasked people gathered in Trafalgar Square to protests about the so-called "new normal" order (The Guardian: September $4,2020)$ while a protest against the government restrictions in Germany took place the same day in Berlin, including over 38,000 participants (RBB: August 29, 2020). Similar protests raised in many cities around the United States (BBC: April 19, 2020), together with the political implications of the presidential election campaign, kept the US federal government from introducing more severe restrictions similar to those implemented in Europe.

Another problem the world faced during the pandemic was that in many countries the statistics about the cases and deaths were forged. This problem has been emphasized by the European Centre for Disease Prevention and Control (ECDC) and WHO which repeatedly expressed a lack of reliability of the data provided. Many countries did not provide real statistics on the spread of the disease and deaths due to COVID-19 for political reasons. Moreover, more than a dozen countries in Africa, Asia, and Eurasia were not connected to the "global COVID-19 disease and death rate" because they did not have access to electronic instrumentation to record data required to be a part of the global database (The Guardian: June 4, 2020).

It should be noted that only the number of deaths in 2019 and 2020 compared to other years can give reliable data on mortality due to COVID-19. For example, in the case of Poland, according to Gazeta Wyborcza article from December 28, 2020 that was based on a comparative big data analysis, in 51 weeks of 2020, 60,000 more people died than in the whole of 2019 - although official statistics show that in 2019 and 2020, a little over 27,000 people died in Poland because of COVID-19. Gazeta Wyborcza's analysis was conducted on the data obtained from the Registers of Civil Status in Poland from 1945 to 2020 and concluded that the pandemic caused the highest mortality rate in Poland in the last 70 years. The mortality rate was similar only in 1951, just six years after the end of the Second World War, and at that time was caused by disability and chronic diseases such as malnutrition, yellow fever, tuberculosis, diphtheria, whooping cough, tetanus, or epidemic typhus (Gazeta Wyborcza: December 28, 2020). In Poland, vaccination against these diseases began only in the late 1950s. Similar research conducted on the data from other countries around the world may offer interesting results.

\subsection{Coping with the pandemic}

Data published by the Bloomberg Covid Resilience Ranking on December 21, 2020 ('The Best and Worst Places to Be in Covid: U.S. Sinks in Ranking' by Rachel Chang, Jinshan Hong and Kevin Varley, published: November 24, 2020, updated: December 21, 2020) shows that many countries around the world are not coping well enough with the pandemic, either in terms of 
healthcare security or economics. Bloomberg's ranking took into account economies whose gross domestic product (GDP) was above $\$ 200$ billion in 2019. The list included 53 countries, including Poland, and the assessment was based on 10 indicators:

- daily increase in infections,

- mortality rate of COVID-19,

- percentage of positive results among all virus tests,

- possibilities of the health care system,

- strengthening of the functioning of enterprises,

- blockade of the functioning of enterprises,

- restrictions on social and political freedoms,

- restrictions on movement,

- quality of pandemic strategy,

- quality of vaccination strategies.

(Bloomberg: December 21, 2020)

These key metrics cover the increase in virus cases to the overall mortality rate and testing capabilities. The capacity of the local healthcare system, the impact of virus-related restrictions like lockdowns on the economy, and freedom of movement are also taken into account.

It should be noted that only data officially provided by national governments were taken into account and that the last two factors included in the ranking reflect the number of doses of vaccine, the number of contracts signed for the supply of vaccine, and the percentage of the population that can be vaccinated with the doses ordered. The percentage of the population that does not want to be vaccinated due to a lack of trust in the vaccine or political power was not taken into account.

According to Bloomberg's ranking, countries such as New Zealand (1st place in the ranking), Taiwan (2), Australia (3), Norway (4), Singapore (5), Finland (6), Japan (7), Korea (8), China (9), and Denmark (10) are best at dealing with the pandemic. The worst include Mexico (53rd; last place in the ranking), Argentina (52), Peru (51), Greece (50), and Italy (49) (Bloomberg: December 21, 2020).

When it comes to the regions of the world, Asia-Pacific countries have the best achievements in the fight against COVID-19, while the worst are noticed in Africa, both Americas and Europe. This is not surprising because the virus first attacked in Asia, while both Europe and the Americas were skeptical of Chinese "revelations" about the "deadly" virus.

In Bloomberg's ranking, Poland, a member of the European Union, was ranked in the low 47th place, one place lower than Iran. What is more, other economies and countries significantly less developed than Poland, including India (39th place), Brazil (36), Nigeria (31), Pakistan (29), Egypt (24), Russia (18), and Vietnam (12), are dealing with COVID-19 much better than Poland. A similar situation is also visible in some other EU countries, 
including Romania (48), Greece (49), and Italy (49), which rank the lowest among European and EU countries (Bloomberg: December 21, 2020).

Difficulties in coping with COVID-19 result in economic decline and healthcare security. Most countries in Africa, Asia, and Latin America will be unable to return to pre-pandemic growth levels until 2023 and to the previous level of per capita income until 2025, later than anywhere else, according to Bloomberg: Covid Resilience Ranking published (Bloomberg: December 21, 2020). Many countries also faced the difficult choice between limiting mortality by announcing a lockdown and trying to maintain the economy by keeping it open.

Still, the countries that have responded most successfully were able to avoid choosing between the two: they avoided the trade-off between high mortality and a high socioeconomic impact of the pandemic. New Zealand and Israel has been able to bring infections down and open up their country internally. Other island nations were also able to almost entirely prevent an outbreak (like Taiwan, Australia, and Iceland). What is more, not only islands were able to bend the curve of infections and prevent large outbreaks - Norway, Uruguay, Thailand, Finland, and South Korea are examples of countries which dealt with the pandemic successfully. These countries not only suffered a smaller direct impact but they also limited the indirect impact because they were able to release lockdown measures earlier (see Our World in Data: January 11, 2021). Unfortunately, the fourth wave of the COVID-19 Pandemic, again shuts down societies and economies in late 2021.

\subsection{Vaccination problems}

Introducing lockdowns and COVID-19 restrictions was only a half-measure. The main goal of the year 2020 was to invent a cure or a vaccine that could successfully deal with the disease and help to end the pandemic. The end of 2020 brought such an invention - several companies worldwide managed to produce a vaccine against the deadly virus, including Pfizer and BioNTech, Moderna, AstraZeneca, Johnson \& Johnson as well as Russian (Sputnik V), and Chinese (Sinovac, Sinopharm) vaccines (Pharmaceutical Processing World: February 5, 2021). In December 2020, the first countries started their vaccination programs. However, with the invention of vaccines, new problems also arose.

The first problem is the reluctance of people to get vaccinated. Many people in the world still downplay the virus. According to a survey conducted by several agencies, institutions, and newspaper editors, it is clear that nearly $50 \%$ of people do not want to get vaccinated. They claim: "99.7\% recovery from COVID-19 - why do we need vaccine" (demonstrator holding an antivaccine placard in east London December 5, 2020).

According to a survey conducted by the Polish Institute for Market and Social Research (IBRiS, Instytut Badań Rynkowych i Społecznych) in 
Poland, only $47 \%$ of the adult population wants to be vaccinated, while $44 \%$ does not want the vaccine and $9 \%$ are not sure. The largest group of those opposing vaccination $(42 \%)$ believe that vaccines were not tested enough because they were created too quickly and thus are dangerous (IBRiS: December 28, 2020).

In the United Kingdom, one in five say they are unlikely to take the vaccine, according to YouGov research published in November 2020, citing a variety of different reasons. Around half of this group (47\%, or $10 \%$ of all Britons) say they simply want to wait and see if the vaccine is safe first. An additional $15 \%$ of this group (equivalent to $3 \%$ of all Britons) currently say they would not get vaccinated because they see themselves as low risk and therefore, do not need the vaccine (YouGov: November 16, 2020).

When it comes to the United States, in December 2020, $42 \%$ of US adults say they would not get a vaccine. This shows a decrease since September 2020 , when $50 \%$ did not want to get a vaccine, according to Gallup Panel 19 , but it still poses significant challenges for public health and government officials in achieving mass public compliance with vaccine recommendations (Gallup 2020).

Another current problem is the insufficient number of vaccines connected with the low pace of vaccine production and the international quest for vaccines among the governments. Although AstraZeneca is planning to produce up to 3 billion doses of the vaccine, Pfizer and BioNTech 1.3 billion, and Johnson \& Johnson, Sinovac, Sinopharm, and Moderna 1 billion doses each (Pharmaceutical Processing World: February 5, 2021), there are still important issues to arise, such as who will be vaccinated first. Since whole populations are to be vaccinated and there are not enough doses produced yet, governments began the vaccination process with different social groups that were considered the most vulnerable: doctors, teachers, critical workers, the elderly, or chronic patients. However, such a vaccination process design also encourages malpractice - the vaccines as well as fake vaccination certificates are already available on the darknet (BBC: March 23, 2021).

Differences in the pace of vaccination are also clearly visible between countries. Israel intends to be the first country to vaccine the whole population with $50 \%$ Israelis fully vaccinated and $60 \%$ having had the first dose as of March 15, 2021. At the same time in the United States, $12 \%$ of the population had been fully vaccinated and $21 \%$ had received the first dose (Health Affairs: March 18, 2021). But while some countries increase the pace of vaccination, other face unexpected delays in the supplies delivered. The European Union had to deal with this problem when Pfizer, AstraZeneca, and Moderna delayed or lowered the numbers of vaccines delivered to the member states at the beginning of 2021 (Reuters: February 17, 2021).

Finally, some experts raise doubts about the effectiveness of the vaccination process itself. With some new mutations in the virus causing the current fourth wave of the pandemic, there are concerns about whether the already 
existing vaccines can successfully prevent this new mutation as well (CNBC: March 5, 2021).

\subsection{New challenges}

Due to the COVID-19 pandemic, the global economy has slowed down significantly. All over the world, apart from New Zealand, people welcomed the New Year 2021 in total or partial lockdown: banned from leaving homes, traveling, with closed hotels and restaurants, and restrictions on the public gatherings for New Year's Eve (depending on the region of the world, up to 5-10 people). Although many people believed that the year 2021 would turn the situation around and allow the world to come back to the pre-pandemic state, new challenges connected with COVID-19 arose in the first quarter of 2021.

In December 2020, a new virus mutation (B.1.1.7) was detected in South Africa and the United Kingdom. Several countries in Europe and the Middle East banned air travel from the United Kingdom because of concerns over a mutant strain of the coronavirus that had been spreading rapidly in England in December 2020. The borders were kept closed also in January 2021; this was particularly difficult for the United Kingdom, which left the European Union on January 1, 2021. The B.1.1.7 mutation is believed to be more adept at human-to-human transmission, causing a much quicker spread of the virus within populations (Science: January 10, 2021). In January, in Japan, another new variant of COVID-19 was also detected - one that appears to have arrived with four passengers who came to Tokyo from Brazil. The newest variant of the virus appears to differ from the highly contagious strains in Britain and South Africa (CNBC: January 11, 2021). The new mutations of the virus shattered the hopes for a quick comeback to the pre-pandemic world and caused the current third wave of the pandemic.

2021 is to become a year of global vaccination. Vaccinations started to be introduced worldwide at the end of December 2020 - firstly, in the medical services and then, depending on the country, targeted at politicians, the elderly or different professional groups. As of December 31, 2020, the first dose of the vaccine had been taken by 2.1 million people worldwide. Most people were vaccinated with the vaccines produced by Pfizer/BioNTech and from January 2020, by Moderna (Our World in Data: January 1, 2021). On the one hand, the vaccines offer hope for a quick return to normality, but on the other hand, some problems with vaccine production and distribution as well as new virus mutations rapidly spreading infections leave people with the question "how will it all end?"

Since the pandemic has proven to be a long-lasting problem for humanity, not just a one-quarter-long anomaly in world development, one of the most pressing current problems is how to adjust to the new situation in the long term. Although we are already facing the fourth wave of the pandemic, many governmental solutions and the state of public healthcare have still 
not been developed enough in many countries to face the ongoing situation. What is more, citizens are not as understanding and mobilized as they were at the beginning of 2020, knowing now that their savings have disappeared, job opportunities have dropped, and hopes for normality are once again delayed. And even if humanity is to successfully combat the COVID-19 pandemic in the near future, there still will be a likely scenario of a big economic crisis for years to come.

\subsection{The costs of the pandemic}

The COVID-19 pandemic has caused a lot of implications for almost every aspect of people's lives. It certainly brought social distance and distrust of others as well as the erosion of public trust in researchers, politicians, and all sorts of "specialists in everything", and above all, the erosion of trust in governments and public institutions. It also has led to a dispersion of trustbased social capital, which money value no one has yet estimated.

What is more, the end of 2020 and the first quarter of 2021 brought numerous restrictions on civil and economic freedoms. In some regions, national governments closed country borders, some of them introducing a total lockdown. On January 5, 2021 a total lockdown was introduced by the United Kingdom, due to the discovery of a new virus mutation.

The first lockdown was introduced in China on November 17, 2019, and on March 1, 2020 the World Health Organization stated that the world was dealing with a pandemic of infectious disease with COVID-19 and suggested that countries "social distance". In the second half of February 2020, big outbreaks of infections with hundreds of patients started in South Korea, Italy, and Iran. Due to the pandemic, travel has been reduced worldwide, quarantine and curfew have been introduced, and a number of sporting, religious, and cultural events have been postponed or cancelled. Many countries have closed their borders or introduced severe restrictions on foreign travel, including restrictions on people crossing borders such as enforcing complete isolation for a period of 10 to 14 days - depending on the country - called "quarantine". Schools and universities went into remote online learning mode, which has affected nearly 1.27 billion students globally (72.4\% of all students) (UNESCO: May 8, 2020). Soon after, enterprises stopped operations and started online work, especially after April 5, 2020, when the threshold of 2 million registered cases was crossed - most of them in the USA, Spain, Italy, and Brazil. Infections in South America have grown rapidly, causing a humanitarian crisis with significant socioeconomic implications. The fear of the virus has caused a decrease in consumer spending and thus, the collapse of traditional trade, transport, tourism and gastronomy around the world.

According to the World Bank, the costs of the pandemic can be divided into three main categories: about $12 \%$ of the total cost comes from increased mortality, $28 \%$ is due to high absenteeism, and as much as $60 \%$ comes from 


\section{Andrzej Nowosad et al.}

behavioral changes - that is because a person tries to avoid another people for fear of being infected. The estimated loss to the world economy as of October 24, 2020 is $\$ 30$ billion, according to the World Bank.

As of February 24, 2020, there have been significant declines in stock markets around the world (Nikkei $-5.3 \%$, Dow Jones - 13.3\%, FTSE $100-19.3 \%)$. What is more, oil prices fell sharply, reaching their lowest price in 30 years on March 9, 2020. Many regions of the world faced a lack of food, and a few faced hunger. Even before COVID-19 reduced incomes and disrupted supply chains, chronic and acute hunger were on the rise due to various factors including conflicts, socioeconomic conditions, natural disasters, climate change, and pests. But 2020 marks the most severe increase in global food insecurity, impacting vulnerable households in almost every country. These phenomena may intensify in the following years because of the economic and agricultural losses, particularly in Latin America, Africa and Asia.

In the first year of the pandemic, transport and tourism industries suffered the most, while trade (especially online) and online games increased their profits. There was a high increase in house prices, caused by a stagnation in the construction industry, which, however, has later fallen due to massive asset sales and the bankruptcy of individuals and businesses (Williams 2020). Currently, the crisis is engulfing the insurance and banking spheres (46\% decrease in profits). In most sectors of the economy, strategies have been put in place to survive and stock up during these uncertain times.

With many economic sectors closed, including tourism, entertainment, restaurants, and shopping malls, and companies unsure how to react in extremely unstable economic and legal conditions, many people lost their jobs and were unable to find a new one, had to do a job they are overqualified for or had their income cut. According to the International Monetary Fund, in 2020 compared with 2019, the unemployment rate rose from $2.4 \%$ to $3.3 \%$ in Japan, from $3.1 \%$ to $4.3 \%$ in Germany, from $3.8 \%$ to $5.4 \%$ in the United Kingdom, from $9.9 \%$ to $11 \%$ in Italy, from $11.9 \%$ to $13.4 \%$ in Brazil, from $3.7 \%$ to as much as $8.9 \%$ in the United States and from $5.7 \%$ to $9.7 \%$ in Canada (BBC: January 24, 2021). This generated significant costs for governments in a form of unemployment allowance and support for companies to prevent further redundancies. The coronavirus pandemic has affected all sectors of the economy, triggering one of the biggest economic crises in the last 100 years. According to the Organisation for Economic Co-Operation and Development (OECD), the COVID-19 pandemic has generated the worst health, economic, and social crisis in our lifetime. No country, no economy, no society has been spared. And no country, no economy, or no society can face it alone. Over 1.1 million people have lost their lives and more than 42 million infections have been recorded so far. In the 2022, we are expected to witness the worst recession since the Second World War, with a projected fall in global GDP of $4.5 \%$. Many economies will not recover their 2019 output levels until 2022 at the 
earliest. The crisis has already wiped out all the jobs created since the global financial crisis of 2008 (OECD: October 10, 2020).

Although it is said that the coronavirus has plunged the world into a "crisis like no other", global growth is expected to rise to $5.8 \%$ in 2022 if the pandemic fades in the second half of 2021 . This forecast is driven primarily by the predicted growth in countries such as India and China. Recovery in big, services-reliant economies that have been hit hard by the COVID-19 outbreak, such as the United Kingdom or Italy, is expected to be a much slower process.

\subsection{Critical mental health services}

Fear, worry and stress are normal responses to perceived or real threats and when people face uncertainty or the unknown. Therefore, it is normal and understandable that people are experiencing fear in the context of the COVID-19 pandemic. The fear of contracting the virus in a pandemic such as COVID-19 is accompanied by the significant changes to our daily lives caused by the restrictions introduced to slow down the spread of the virus. When facing the new realities of working from home, temporary unemployment, home-schooling, and a lack of physical contact with other family members, friends, and colleagues, we need to look after both our mental and physical health.

The COVID-19 pandemic has disrupted or halted critical mental health services in $93 \%$ of countries worldwide while the demand for mental health care is increasing, according to a new WHO survey. The survey of 130 countries provides the first global data showing the devastating impact of COVID-19 on access to mental health services. According to WHO, the pandemic is increasing demand for mental health services. Bereavement, isolation, loss of income, and fear are triggering mental health conditions or exacerbating existing ones. Many people may be facing increased levels of alcohol and drug use, insomnia, and anxiety.

What is more, COVID-19 itself can lead to neurological and mental complications, such as delirium, agitation, and stroke. People with pre-existing mental, neurological or substance use disorders are also more vulnerable to SARS-CoV-2 infection - they may stand a higher risk of severe outcomes and even death. While many countries $(70 \%)$ have adopted telemedicine or teletherapy to overcome disruptions to in-person services, there are significant disparities in the uptake of these interventions. More than $80 \%$ of high-income countries reported deploying telemedicine and teletherapy to bridge gaps in mental health, compared with less than $50 \%$ of low-income countries.

According to the WHO survey, countries reported widespread disruption of many kinds of critical mental health services, including:

- over $60 \%$ reported disruptions to mental health services for vulnerable people, including children and adolescents (72\%); older adults (70\%); and women requiring antenatal or postnatal services $(61 \%)$; 


\section{Andrzej Nowosad et al.}

- disruptions to counseling and psychotherapy were reported by $67 \%$; $65 \%$ reported disruptions to critical harm reduction services; and $45 \%$ to opioid agonist maintenance treatment for opioid dependence;

- more than a third $(35 \%)$ reported disruptions to emergency interventions, including those for people experiencing prolonged seizures; severe substance use withdrawal syndromes; and delirium, often a sign of a serious underlying medical condition;

- disruptions to access to medications for mental, neurological and substance use disorders were reported by $30 \%$;

- around three-quarters reported at least partial disruptions to school and workplace mental health services ( $78 \%$ and $75 \%$ respectively).

(WHO: October 5, 2020)

\subsection{COVID-19 databases}

Thanks to the Internet, it is possible to check the status of the pandemic daily. The most popular databases of active cases of COVID-19 include:

- Worldometers (https://www.worldometers.info/coronavirus/), based on Geoshemie UN public statistics (https://unstats.un.org/unsd/methodology/m49/),

- WHO Coronavirus Disease (COVID-19) Dashboard (https://covid19. who.int/),

- Our World in Data (https://ourworldindata.org/coronavirus-data),

- OCHA - Asia Pacific COVID-19: Humanitarian Data Portal (https:// interactive.unocha.org/data/ap-covid19-portal/),

- The Coronavirus in Asia and ASEAN - Live Updates by Country (https:// www.aseanbriefing.com/news/coronavirus-asia-asean-live-updates-bycountry/),

- COVID-19 Research Response. The Global Health Network (https:// coronavirus.tghn.org/regional-response/asia-ncov/),

- The Lancet - Regional Health (https://www.thelancet.com/journals/laninf/article/PIIS1473-3099(20)30708-8/fulltext),

- The South African Resource Portal (https://sacoronavirus.co.za/),

- CDC - Centers for Disease Control and Prevention, US Federal Government Agency, Part of the Department of Health and Human Services (https://www.cdc.gov/coronavirus/2019-ncov/covid-data/covidview/index.html),

- Europe: European Centre for Disease Prevention and Control, An Agency of the European Union (https://www.ecdc.europa.eu/en/covid19/data),

- Eurostat - COVID-19: Statistics Serving Europe (https://ec.europa.eu/ eurostat/web/covid-19/overview). 


\subsection{Conclusions}

The COVID-19 pandemic has taken the world and world leaders by surprise, significantly changing all aspects of our lives. The virus and the disease spread so quickly and took so many lives around the world that it has become the most important topic of 2020 and 2021, influencing all aspects of the economy, society, politics, and culture. No part of humanity was spared - many people are dying, healthcare systems are collapsing, economies are suffering because of lockdown, governments are facing distrust and in some countries are even facing uprisings of people who are dissatisfied with the way the COVID-19 crisis has been handled.

In the face of the crisis, it is no wonder that COVID-19 has immediately become the main topic of research conducted around the world in a wide range of disciplines - from medicine and virology to social sciences trying to explain its impact on society and its members. Large amounts of funds targeted at all types of COVID-19 research projects led to a lot of important discoveries, including different types of tests, medical procedures to treat COVID-19 patients, statistics allowing for study of the development of the pandemic, and finally vaccines against the deadly virus. However, despite all these applied studies and recent discoveries, humanity still faces a lot of problems connected with the virus's impact.

One of the most important problems is denial of the virus's existence and miscalculated statistics on its spread. Not every government and politician took the disease seriously and many of them tried to use the situation for their own political gain. As a consequence, in some countries governments did not act upon the virus as quickly and forcefully as they could have done, causing severe implications not only for these countries but also for their neighbors.

What is more, the lack of knowledge about the origins or initial spread of the virus combined with miscalculated data on the scope of pandemic has led to many misunderstandings, mistakes, and even conspiracy theories, which unfortunately have been spread through the media and the Internet, affecting numerous people. Politicians and different kinds of 'experts' did not stop these revelations which only fueled them and led to social and political distrust to the extent that when the vaccine for the COVID-19 was finally introduced, huge parts of society did not want to take it for fear of the possible side effects or mistrust for the government.

There is also huge economic loss connected with the COVID-19 pandemic. The global economy, which became a highly interconnected network during the last 30 years, started to split and collapse. Many branches which were based on international exchange and social contacts, especially services, have suffered a lot since the very beginning of the pandemic. Others have been hit hard later, when initial lockdowns led to unemployment, withdrawal of assets, and general pessimism when it comes to investments. 
All these factors combined allow experts to predict the occurrence of a big economic crisis connected with the pandemic in the near future.

Economic pressures are also closely connected with social loss. Although globalization in the last 30 years allowed for the quick development of ideas and improvement of life conditions, the virus caused a lot of personal and social damage. Problems such as the deaths of people who may otherwise have lived for much longer time, unemployment, healthcare, and mental health problems, home-schooling, lack of contact with others, and decrease of trust will probably be the long-lasting effects of the COVID-19 pandemic.

\section{References}

Andersen, K., Rambaut, A., Lipkin, W., Holmes, E., Garry, R. (2020) Correspondence: The proximal origin of SARS-CoV-2. Nature Medicine. No. 26 (4), 450-452.

Baltimore, D. (1971). Expression of animal virus genomes. Bacteriological Reviews. No. 35 (3), 235-241.

BBC (February 11, 2020). Coronavirus disease named Covid-19. Archived from the original on 15 February 2020. Retrieved January 15, 2021.

BBC (April 19, 2020). Coronavirus: US protests against and for lockdown restrictions. Retrieved March 25, 2021. https://www.bbc.com/news/av/world-uscanada-52344540.

BBC (January 24, 2021). Coronavirus: How the pandemic has changed the world economy. Retrieved March 30, 2021. https://www.bbc.com/news/business51706225.

BBC (March 23, 2021). Covid-19: Vaccines and vaccine passports being sold on darknet. Retrieved March 25, 2021. https://www.bbc.com/news/technology56489574.

Bloomberg (December 21, 2020). Rachel Chang, Jinshan Hong, Kevin Varley, The Covid resilience ranking. The best and worst places to be in covid: U.S. sinks in ranking. Bloomberg. November 24, 2020, Updated: December 21, 2020, Retrieved 15 January 2021. https://www.bloomberg.com/graphics/covidresilience-ranking/.

CDC (February 11, 2020). About novel coronavirus (2019-nCoV). Archived from the original on February 11, 2020. Retrieved February 25, 2020. https://www. who.int/docs/default-source/coronaviruse/situation-reports/20200130-sitrep-10ncov.pdf?sfvrsn=d0b2e480_2.

CDC-Led Collaboration (2012). First global estimates of 2009 H1N1 pandemic mortality released. cdc.gov. June 25, 2012. Access: January 10, 2021. https:// www.cdc.gov/flu/spotlights/pandemic-global-estimates.htm; https://www. thelancet.com/journals/laninf/article/PIIS1473-3099(12)70121-4/fulltext.

Chan, J., Yuan, S., Kok, K., To, K., Chu, H., Yang, J., et al. (2020). A familial cluster of pneumonia associated with the 2019 novel coronavirus indicating person-toperson transmission: A study of a family cluster. The Lancet. No. 395 (10223), $514-523$. 
CNBC (March 5, 2021). How the different Covid vaccines will handle new variants of the virus. Retrieved March 25, 2021. https://www.cnbc.com/2021/03/05/ how-the-different-covid-vaccines-will-handle-variants.html.

CNBC TV (January 11, 2021). Japan has found a new Covid variant. Here's how it compares to virus strains in the UK. South Africa. Retrieved January 11, 2021. https://www.cnbc.com/2021/01/11/japan-covid-variant-how-it-compares-tostrains-in-uk-south-africa.html.

CSSE - Center for Systems Science and Engineering (January 11, 2021). COVID19 dashboard by the center for systems science and engineering (CSSE) at Johns Hopkins University (JHU). ArcGIS, Johns Hopkins University, Coronavirus Resource Center. Retrieved January 10, 2021. https://coronavirus.jhu.edu/map .html.

Gallup (November 17, 2020). More Americans now willing to get COVID-19 vaccine. Archived from the Retrieved original on January 10, 2021. https://news .gallup.com/poll/325208/americans-willing-covid-vaccine.aspx.

Gazeta Wyborcza (December 28, 2020). Zgony. Niestety, 2020 r. zapisze sie w naszej powojennej historii jako rekordowy, edited by Pawłowska, D. "Gazeta Wyborcza BiQ DATA.pl” BiG DATA.pl, Retrieved December 28, 2020. https:// biqdata.wyborcza.pl/biqdata/7,159116,26642808,zgony-niestety-2020-r-zapisze -sie-w-naszej-powojennej-histori.html.

Gorbalenya, A. E., Baker, S. C., Baric, R. S., de Groot, R. J, Drosten, C., Gulyaeva, A. A., et al. (2020). The species Severe acute respiratory syndrome-related coronavirus: Classifying 2019-nCoV and naming it SARS-CoV-2. Nature Microbiology. No. 5 (4), 536-544.

Health Affairs (March 18, 2021). Lessons In COVID-19 vaccination from Israel. Retrieved March 25, 2021. https://www.healthaffairs.org/do/10.1377/ hblog20210315.476220/full/.

IBRIS (December 28, 2020). Polish institute for market and social research. Survey: Wciaż sporo osób nie chce sie zaszczepić. Dominuje jeden argument przeciw. 'Rzeczpospolita'. Retrieved December 28, 2020. https://wiadomosci.onet.pl/kraj/ koronawirus-sondaz-ile-osob-w-polsce-chce-sie-zaszczepic/9m6pr2k.

Johns Hopkins University (March 25, 2021). COVID-19 dashboard. Retrieved March 25, 2021. https://coronavirus.jhu.edu/map.html.

Lim, B. H., Mahmood, T. A. (2011). Influenza A H1N1 2009 (Swine Flu) and pregnancy. Journal of Obstetrics and Gynaecology. No. 61 (4), 386-393.

Machhi, J., Herskovitz, J., Senan, A. M., Dutta, D., Nath, B., Oleynikov, M. D., et al. (2020). The natural history, pathobiology, and clinical manifestations of SARS-CoV-2 infections. Journal of Neuroimmune Pharmacology. The Official Journal of the Society on Neuroimmune Pharmacology. No. 15 (3), 359-386.

NIH - National Institutes of Health (March 17, 2020). New coronavirus stable for hours on surfaces. NIH.gov. Archived from the original on March 23, 2020. Retrieved May 4, 2020. https://www.nih.gov/news-events/news-releases/ new-coronavirus-stable-hours-surfaces.

OECD (October 10, 2020). Ministerial council meeting opening remarks by Angel Gurría. OECD Secretary-General. Retrieved January 10, 2021. https:/www.oecd. org/coronavirus/en/.

Our World in Data (January 1, 2021). How many people have received a coronavirus vaccine? Retrieved January 10, 2021. https://ourworldindata.org/ covid-vaccinations. 
Pharmaceutical Processing World (February 5, 2021). Which companies will likely produce the most COVID-19 vaccine in 2021? Retrieved March 25, 2021. https://www.pharmaceuticalprocessingworld.com/which-companies-will-likely -produce-the-most-covid-19-vaccine-in-2021/.

RBB (August 29, 2020). Fast 40.000 Menschen bei Corona-Demos - Sperren am Reichstag durchbrochen. Retrieved March 25, 2021. https://www.rbb24. de/politik/thema/2020/coronavirus/beitraege_neu/2020/08/demonstrationensamstag-corona-querdenken-gegendemos.html.

Reuters (June 26, 2020). Coronavirus traces found in March 2019 sewage sample, Spanish study shows. Archived from the original on June 26, 2020 7:22 PM. Retrieved January 10, 2021. https://www.reuters.com/article/us-healthcoronavirus-spain-science-idUSKBN23X2HQ.

Reuters (February 17, 2021). Exclusive: Pfizer COVID-19 vaccine supply to the EU about 10 million doses short of plan -sources. Retrieved March 25, 2021. https://www.reuters.com/article/us-health-coronavirus-eu-pfizer-exclusividUSKBN2AH1E3.

Sanche, S., Lin, Y. T., Xu, C., Romero-Severson, E., Hengartner, N., Ke, R. (2020). High contagiousness and rapid spread of severe acute respiratory syndrome coronavirus 2. Emerging Infectious Diseases. No. 26 (7), 1470-1477.

Science (January 10, 2021). Kupferschmidt Kai, Mutant coronavirus in the United Kingdom sets off alarms, but its importance remains unclear, Science's COVID-19 reporting. Retrieved January 10, 2021. https://www.sciencemag.org/news/2020/12/ mutant-coronavirus-united-kingdom-sets-alarms-its-importance-remains-unclear.

Scientific American (October 12, 2020). Eight persistent COVID-19 myths and why people believe them. Retrieved March 25, 2021. https:/www.scientificamerican .com/article/eight-persistent-covid-19-myths-and-why-people-believe-them/.

Shou-Jiang, G. (ed.) Journal of Medical Virology. Three special issues on the Novel Coronavirus (COVID-19), monthly editions for years 2019-2020. Retrieved January 10, 2021. https://onlinelibrary.wiley.com/journal/10969071; https:// papers.ssrn.com/sol3/papers.cfm?abstract_id=3557504.

The Guardian (May 1, 2020). Trump claims to have evidence coronavirus started in Chinese lab but offers no details. Support the Guardian. Retrieved January 10, 2020. https:/www.theguardian.com/us-news/2020/apr/30/donald-trump -coronavirus-chinese-lab-claim.

The Guardian (June 4, 2020). Covid-19 investigations unreliable data: How doubt snowballed over Covid-19 drug research that swept the world. The Guardian. Retrieved January 10, 2021. https://www.theguardian.com/world/2020/jun/ 04/unreliable-data-doubt-snowballed-covid-19-drug-research-surgispherecoronavirus-hydroxychloroquine; https://papers.ssrn.com/sol3/papers.cfm ?abstract_id=3557504.

The Guardian (September 4, 2020). How coronavirus has brought together conspiracy theorists and the far right. Retrieved March 25, 2021. https://www. theguardian.com/commentisfree/2020/sep/04/coronavirus-conspiracy-theoristsfar-right-protests.

The Guardian (October 26, 2020). Survey uncovers widespread belief in 'dangerous' Covid conspiracy theories. Retrieved March 25, 2021. https://www.theguardian. com/world/2020/oct/26/survey-uncovers-widespread-belief-dangerous-covidconspiracy-theories. 
UNESCO (May 8, 2020). COVID-19 educational disruption and response. Retrieved January 10, 2021. https://en.unesco.org/news/covid-19-educational-disruption -and-response; https://papers.ssrn.com/sol3/papers.cfm?abstract_id=3557504.

WHO - World Health Organization (January 2020). Surveillance case definitions for buman infection with novel coronavirus ( $n \mathrm{CoV})$ : Interim guidance $v 1$, January 2020 (report). Retrieved January 10, 2021. https://papers.ssrn.com/sol3/papers .cfm?abstract_id=3557504;hdl:10665/330376.WHO/2019-nCoV/Surveillance/v 2020.1.=

WHO - World Health Organization (January 30, 2020). Statement on the second meeting of the International Health Regulations (2005) Emergency Committee regarding the outbreak of novel coronavirus (2019- $n$ CoV). (Press release). Archived from the original on January 31, 2020. Retrieved January 10, 2021. https://www.who.int/news/item/30-01-2020-statement-on-the-second-meetingof-the-international-health-regulations-(2005)-emergency-committee-regardin g-the-outbreak-of-novel-coronavirus-(2019-ncov).

WHO - World Health Organization (March 11, 2020). WHO Director-General's opening remarks at the media briefing on COVID-19 - 11 March 2020. (Press release). Archived from the original on March 11, 2020. Retrieved March 12, 2020. https://www.who.int/director-general/speeches/detail/who-director-generals-opening-remarks-at-the-media-briefing-on-covid-19---11-march-2020.

WHO - World Health Organization (October 5, 2020). COVID-19 disrupting mental health services in most countries, WHO survey. World Mental Health Day on 10 October to highlight urgent need to increase investment in chronically underfunded sector, October 5, 2020. https://www.who.int/news/item/0510-2020-covid-19-disrupting-mental-health-services-in-most-countries-whosurvey.

Williams, C. Ch. (2020). Impacts of the coronavirus pandemic on Europe's tourism industry: Addressing tourism enterprises and workers in the undeclared economy. International Journal of Tourism Research. No. 23 (1): 79-88. Retrieved July 27, 2020. https://doi.org/10.1002/jtr.2395.

WMD - Worldometer Data. Archived from the original on January 31, 2020. Retrieved September 9, 2021. https://www.worldometers.info/coronavirus/. 